\title{
Geoelectrical and Electromagnetic Methods Applied to Paleolimnological Studies: Two Examples from Desiccated Lakes in the Basin of Mexico
}

Matthias Bücker, Socorro Lozano García, Beatriz Ortega Guerrero, Margarita Caballero, Liseth Pérez, Lizeth Caballero, Carlos Pita de la Paz, Alfredo Sánchez-Galindo, Francisco Jesús Villegas, Adrián Flores Orozco, Erik Brown, Josef Werne, Blas Valero Garcés, Antje Schwalb, Andreas Kemna, Edgar Sánchez-Alvaro, Norberto Launizar-Martínez, Antonio Valverde-Placencia, Fernando Garay-Jiménez

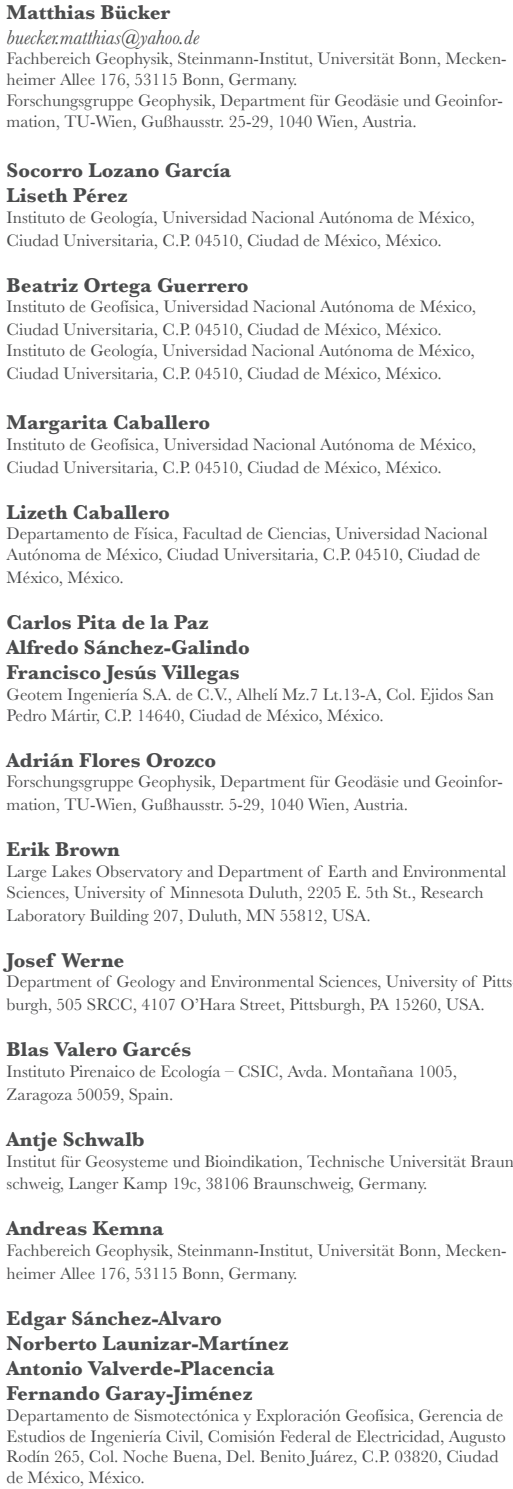

\begin{abstract}
Paleolimnological studies require a broad understanding of the geometry and depth of the sedimentary fill of lake basins prior to coring campaigns. Seismic methods are routinely employed for the indirect characterization of lake-bottom sediments. However, the use of seismic methods might occasionally be limited due to surface conditions or poor seismic contrasts between the stratigraphic units, which lead to data quality that is too poor to provide sufficient information for the selection of drill sites. Sources of cultural noise are one of the main reasons why seismic methods fail in study areas near or within large cities, such as Mexico City. Under certain conditions, electrical and electromagnetic methods might be a suitable substitute or complement to seismic exploration, as they respond to different physical properties of the subsurface. To evaluate the applicability of such methods, here we present two recent case studies from the desiccated lakes Chalco and Xochimilco both located in urban areas within the Basin of Mexico where electrical resistivity tomography (ERT), transient electromagnetic (TEM) and magnetotelluric (MT) soundings were conducted for the characterization of lake basement and lacustrine sediments. In both examples, the results of the geophysical exploration contributed valuable stratigraphic information for the following drilling and core recovery, which highlights the potential of electrical and electromagnetic methods in paleolimnological studies.
\end{abstract}

Keywords: Geophysics, electrical resistivity tomography, electromagnetic methods, paleolimnology, lacustrine sediments, Mexico.

\section{RESUMEN}

Los estudios paleolimnológicos requieren de una base amplia de información sobre la geometría y la profundidad de los paquetes sedimentarios de las cuencas lacustres antes de la extracción de núcleos. Comúnmente, se emplean métodos sísmicos para la caracterización indirecta de los sedimentos acumulados en los fondos de los lagos. Sin embargo, en ocasiones el uso de métodos sísmicos puede ser limitado debido a las condiciones superficiales, contrastes sísmicos reducidos entre las unidades estratigráficas de interés o a una calidad de datos insuficiente para la selección de los sitios de perforación. Las fuentes de ruido cultural son la principal razón por la que métodos sísmicos fallan en sitios de estudio ubicados cerca de o dentro de ciudades grandes, como la Ciudad de México. Bajo ciertas condiciones, métodos eléctricos y electromagnéticos pueden sustituir o complementar la exploración sísmica, ya que responden a otras propiedades fisicas del subsuelo. Para evaluar la aplicabilidad de estos métodos, se presentan dos estudios de caso realizados en los antiguos lagos de Chalco y Xochimilco, ambos ubicados en áreas urbanas dentro de la Cuenca de México, en los que se realizaron mediciones de tomografia de resistividad eléctrica (TRE), sondeos electromagnéticos por transitorios (TEM) y sondeos magnetotelúricos (MT) para caracterizar el basamento y los sedimentos lacustres. En ambos ejemplos, los resultados de la exploración geofisica brindaron información estratigráfica valiosa para la posterior perforación y recuperación de núcleos, lo cual evidencia el potencial de los métodos eléctricos y electromagnéticos para estudios paleolimnológicos.

Palabras clave: Geofísica, tomografía de resistividad eléctrica, métodos electromagnéticos, paleolimnología, sedimentos lacustres, México. 


\section{Introduction}

Lakes are important sentinels and integrators of the effects of climate and environmental change (Schindler, 2009), and lacustrine sediments are natural archives of these past changes. Stratigraphic analysis of biological and non-biological indicators in lacustrine sediment cores provides information on direct and indirect climate-lake interactions in the past (Fritz, 1996).

Most lakes in the northern Neotropics originated during the early Holocene, 10000 years ago, when temperature and precipitation increased. A few water bodies, however, are much older and were shown to have consistently held water during the late Pleistocene, e.g. Lake Chalco in central Mexico ( 500000 years) (Brown et al., 2012) and Lake Petén Itzá in northern Guatemala ( 400000 years) (Kutterolf et al., 2016). Recovery of such long sedimentary sequences requires specialized equipment and personnel, which are generally expensive (Dean, 2010).

Therefore, basin surveys need to be conducted prior to drilling operations for a careful planning and an efficient use of the drilling budget, even for smaller scale projects (Cohen, 2003). Essential data comprises but is not limited to sediment thickness and composition, depth to bedrock and possible heterogeneities within the lake sediments (Last and Smol, 2001). Ideally, these parameters are available on the lake-basin scale to allow a well-founded selection of the drilling site. However, even smaller-scale information on the subsurface conditions in the vicinity of the selected site can aid drilling operations. If no data is available from collocated boreholes, geophysical methods are an efficient alternative to gain information on the subsurface (e.g. Telford et al., 1990). A great advantage of most geophysical exploration methods is that they are non-invasive, relatively low-cost and able to quickly provide quantitative results.

While a wide range of applied geophysical methods exists for near-surface studies, seismic reflection methods are most widely used to assist the planning and execution of drilling projects for paleolimnological studies (e.g. Scholz, 2001). Due to the typically large contrast between the mechanical properties, i.e. seismic velocities and the bulk density, of the relatively soft lake sediments and the underlying hard bedrock, seismic reflection methods are particularly well-suited to map the depth of this lithological interface and the thickness of lake sediments. However, under certain circumstances, possibilities to carry out (active) seismic surveys might be limited or the quality of the seismic data might not be sufficient for the project's purpose (e.g. Lozano-García et al., 2017). Amongst other, limiting factors can be (1) insufficient contrasts among the seismic velocities of geologic materials, (2) the presence of gas-charged lake-floor sediments that act as a strong reflector and mask underlying sediments (e.g. Davy, 1992) or (3) sources of natural and/or cultural noise in the study area. Particularly in densely populated urban areas, where e.g. ground traffic and industrial facilities might represent important sources of noise, the execution of seismic surveys might be challenging (e.g. Liberty, 2011). Furthermore, the use of explosives or large seismic sources, which are often used for land-seismic surveys might be restricted in urban areas and/or natural conservation zones often encountered in the vicinity of lakes.

In some cases, geoelectrical (e.g. Binley and Kemna, 2005) and electromagnetic (e.g. Kaufman et al., 2014) methods can be a suitable alternative to seismic surveys, gain complementary information, or reduce the uncertainty in the interpretation of seismic results. In order to make these techniques available to the broader community of paleolimnological researchers, in this paper we briefly introduce some of the most commonly used geoelectrical and electromagnetic methods. In particular, we present the basic relations between the electrical resistivity and the key petrophysical parameters of geologic materials. The electrical resistivity (i.e. the inverse of the electric conductivity) is the physical quantity retrieved from all three methods discussed in this paper, namely, Electrical 
Resistivity Tomography (ERT), Transient Electromagnetic (TEM) soundings, and Magnetotelluric (MT) soundings.

In order to evaluate the possibilities and limitations of these geophysical methods applied to paleolimnological studies we present two case histories from the Basin of Mexico. This research was in collaboration with scientists from the Institutes of Geology and Geophysics from the Universidad Nacional Autónoma de México (UNAM) as well as international cooperation partners. The first example presents the results of an ERT survey at the former Lake Xochimilco, with a maximum exploration depth of $100 \mathrm{~m}$ that was carried out prior to retrieving a $47 \mathrm{~m}$ sediment core. The second example presents the results of TEM and MT soundings from the vicinity of the International Continental Drilling Program (ICDP) site at the ancient Lake Chalco (Brown et al., 2012). Both study sites have a particular geological context, where lake sediments are in contact with different volcanic materials, such as basalt layers and thick pyroclastic deposits. These materials, which are typical for the Basin of Mexico, are characterized by sufficiently contrasting electric properties, which facilitates the success of this type of geophysical exploration. Furthermore, the availability of stratigraphic data from the collocated drilling at both sites allowed us to evaluate and discuss the potential of the applied geophysical methods.

\section{Material and method}

\subsection{ELEGTRICAL RESISTIVITY OF GEOLOGIGAL MEDIA}

Sediments and sedimentary rocks are composed of solid mineral grains of different size and the pore space between the grains, which is occupied by varying fractions of air and water. Except for rarer metallic minerals, most rock-forming minerals are poor electrical conductors and do not contribute significantly to the electrical conductivity of these media (e.g. Telford et al., 1990). Instead, the electric current is carried by ions dissolved in the pore water (electrolytic conduction) and even a thin film of water at the mineral surface of an interconnected pore network can increase the electrical conductivity by orders of magnitude. Consequently, in (partially) water saturated media the electric conductivity is directly proportional to the electrical conductivity of the pore water and increases with the porosity of the material (volume fraction of free pore space) and the water saturation. However, this empirical relationship, also known as "Archie's law" (Archie, 1942), only holds for clay-free sediments. Generally, clay minerals have high cation exchange capacities leading to the build-up of electrical double layers at the water-mineral interface (e.g. Waxman and Smits, 1968). The resulting high excess ion concentration accumulated at the interface further increases the electrical conductivity of clay-bearing sediments. The connectivity between pores is typically low in metamorphic and igneous rock such as basalt but also decreases in sedimentary rocks with the degree of compaction and cementation of the sediments (e.g. Telford et al., 1990). Therefore, the electrical resistivity of hard rock is typically much higher than that of unconsolidated sediments and is only decreased by weathering and/or fracturing, which allow pore water to re-connect and carry electrical current.

In the application of geophysical methods for the characterization of sedimentary basins, the electrical resistivity will act as a "proxy" for those petrophysical properties it largely depends on, i.e. porosity, clay content, cementation/compaction, water saturation, and pore-water conductivity. While the first three properties are directly linked to lithology, and thus the measured resistivity offers an indirect access to stratigraphic information, varying water saturation and water conductivity can occasionally dominate the electrical response of the subsurface materials and mask lithological contacts. 


\subsection{ELECTRICAL RESISTIVITY TOMOGRAPHY (ERT)}

For geoelectrical measurements two electrodes are firmly attached to the surface in order to inject an electric current into the ground, while another pair of electrodes is used to measure the resulting voltage (Figure 1). The measured voltage varies with the geometrical configuration of the four electrodes but also depends on the electrical resistivity of the subsurface. From the voltage to current ratio and considering the geometric configuration of the electrodes, an apparent resistivity of the measurement can be calculated. For a homogeneous subsurface, this apparent resistivity is equal to the homogeneous electrical resistivity. However, in most cases, the electrical resistivity varies in the vertical and/or horizontal direction. In order to assess vertical resistivity variations, the distances between the electrodes can be increased stepwise, which allows the electrical current to penetrate increasingly larger depths. To determine lateral contacts only, the four-point measurement must be repeated at different positions along a profile maintaining fixed distances between the electrodes. For a tomographic measurement these two approaches are combined and typically hundreds

\section{a) Four-point measurement}

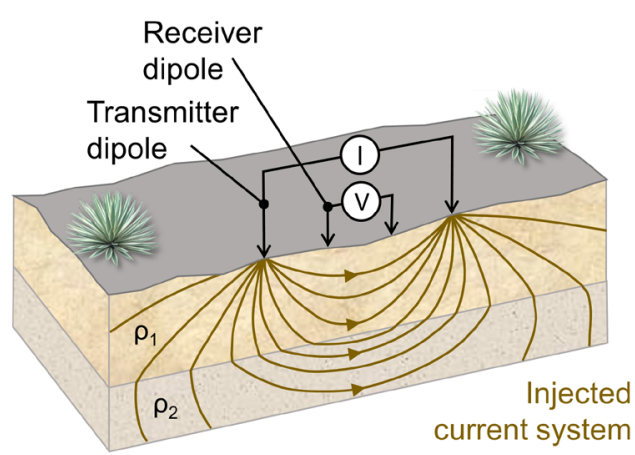

of four-point measurements with varying electrode apertures are collected at different positions along the line (e.g. Binley and Kemna, 2005). Modern tomographic measurement systems automatically control hundreds of electrodes and measure thousands of four-point configurations. Depending on the survey objective, different geometric arrays are commonly used. Figure 1 illustrates three typically deployed electrode configurations known as dipole-dipole, Wenner, and pole-dipole array, employed in the first case study of this work. For the interpretation of the tomographic measurement, apparent resistivities need to be "inverted". This task is realized by inversion algorithms, which adjust an approximate block model of electrical resistivities that reproduces the measured apparent resistivities within a certain margin of error. The results of this processing are 2D-sections of the electrical resistivity beneath the profile, which represent the spatial variation of the electrical resistivity in the subsurface.

\subsection{TRANSIENT ELECTROMAGNETIC (TEM) SOUNDINGS}

Transient electromagnetic (TEM) soundings, also known as time-domain electromagnetic sound-

\section{b) Electrode configurations}

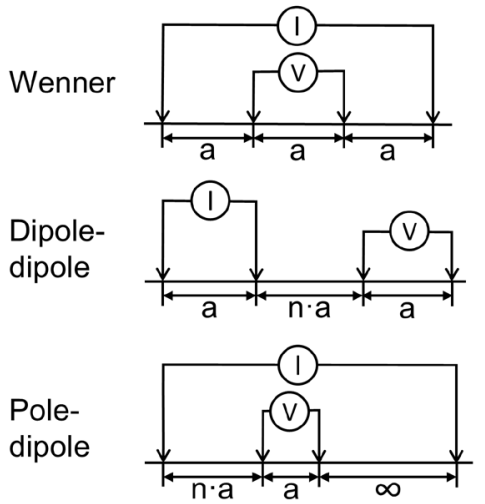

Figure 1 a) Schematic representation of a geoelectrical four-point measurement; a direct current $l$ is injected through a pair of electrodes and the resulting voltage $V$ is measured between two other electrodes. The flow paths of the electrical current in the subsurface depend on the electrical resistivities $\rho 1, \rho 2$ of the stratigraphic units. b) Common electrode configurations: Wenner (top), dipole-dipole (centre), and pole-dipole (bottom) array. 
ings, can be carried out in many different ways (e.g. Telford et al., 1990). For the most commonly applied TEM soundings an electric current is injected into a horizontal loop consisting of a simple cable extended on the terrain (Figure 2). The current carrying loop acts as a magnetic coil, which generates a primary magnetic field that extends into the subsurface. Then the transmitter current is abruptly interrupted causing the decay of the magnetic field, which by means of electromagnetic (EM) induction causes eddy currents to flow in the subsurface. Within milliseconds, the induced current system diffuses into the subsurface moving downwards and extending itself laterally. The temporal variation of this current system in turn generates a secondary magnetic field, the evolution of which can be measured at the surface. Typically, a smaller receiver coil does this, but it can also be realized with the transmitter loop itself (single-loop TEM), which reduces the effort in the field.

Figure 2 shows the variation of the time derivative of the secondary magnetic field, also known as impulse response, for different simple layered-earth models. As the magnitude and the temporal evolution of the secondary magnetic field depend on the subsurface resistivity, TEM sounding data can be

\section{a) TEM principle}

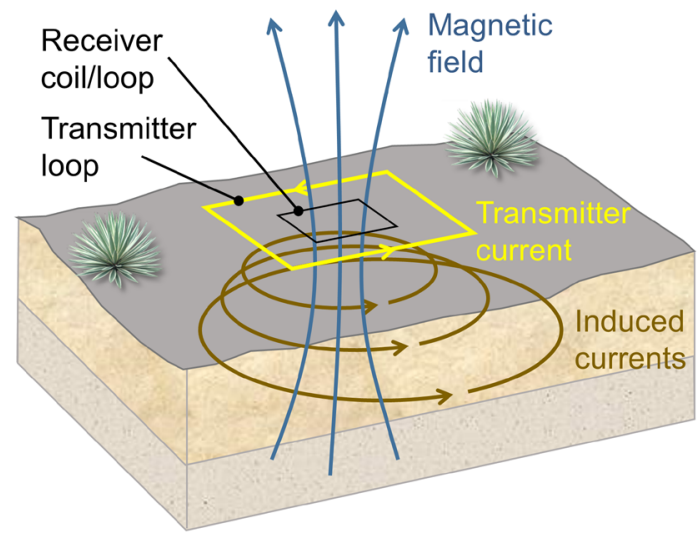

used to reconstruct the geometric distribution of stratigraphic units with different electrical properties. Similar to ERT measurements, the field data must be inverted in order to obtain resistivity models representing the subsurface materials.

Because the depth of the current system increases with time, but at the same time the signal strength decreases, the investigation depth of TEM soundings is largely determined by the effective signalto-noise $(\mathrm{S} / \mathrm{N})$ ratio of the measurement. The effective $\mathrm{S} / \mathrm{N}$ ratio can either be increased by stacking (averaging) repeated measurements or by increasing the transmitter dipole moment, which is the product of injected current times loop area. Consequently, large loops (up to $500 \mathrm{~m}$ x $500 \mathrm{~m}$ square loops) are generally used for deep soundings and small loops (a few decimetres to meters) for shallow investigations. As a rule of thumb, the investigation depth of a TEM sounding is about 2-3 times the loop diameter.

\subsection{MAGNETOTELLURIC SOUNDINGS (MT)}

Like the TEM method, the magnetotelluric (MT) method is based on the EM induction of electric currents in the subsurface. However, instead of using an active source, the MT method makes use

\section{b) Impulse responses}

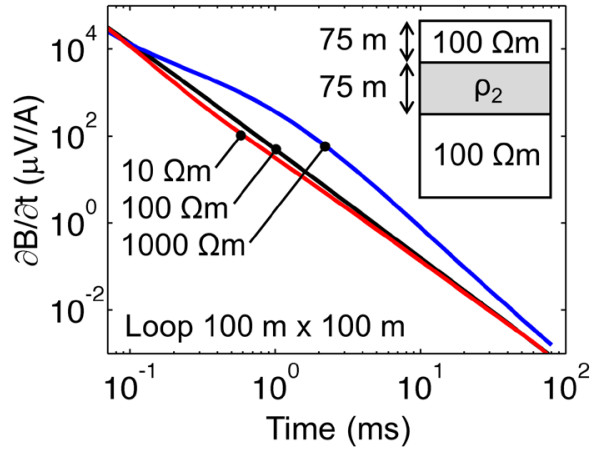

Figure 2 a) Schematic representation of an in-loop TEM sounding: A direct current is injected into the transmitter loop. After current shut-off, eddy currents are induced that diffuse into the subsurface. The receiver coil or loop placed in the centre of the transmitter loop detects the transient voltage induced by the decaying secondary magnetic field. b) Impulse responses (time derivative of the secondary magnetic field) for three different layered-earth models. The resistivities of the first and the last layer are fixed to $100 \Omega \mathrm{m}$, the resistivity of the second layer 22 is $10 \Omega \mathrm{m}$ (red curve), $100 \Omega \mathrm{m}$ (black curve), and $1000 \Omega \mathrm{m}$ (blue curve). 
of EM waves originating from ionospheric and magnetospheric currents, electrical storms and long-wave radio transmitters. The temporal variations of the magnetic components of these waves induce electrical currents in the subsurface, which in turn generate secondary magnetic fields. For MT soundings, the superposition of both primary and secondary magnetic field, as well as primary and secondary electric field, are measured at the surface. Figure 3 illustrates the setup of a typical MT station, including two electric dipoles that measure the two horizontal components of the electric field $\left(E_{x}\right.$ and $\left.E_{y}\right)$, as well as three magnetic induction coils for the measurement of the two horizontal $\left(H_{x}\right.$ and $\left.H_{y}\right)$ and the vertical $\left(H_{z}\right)$ component of the magnetic field.

The ratio of the electric to the perpendicular magnetic field is then used to compute the apparent resistivity. Together with the phase, which quantifies the temporal delay between the electric and magnetic component of the EM wave, the apparent resistivity describes the measured impedance at the MT sounding site. The penetration depth of an EM wave in a conducting medium (the subsurface) depends on the oscillation frequency of the wave. In order to relate the measured time-series of the magnetic and electric fields $\left(H_{x}(t), E_{y}(t)\right.$, etc.) to the resistivity variation in the subsurface, they are decomposed into the different frequency components of the incident EM wave. Again with the help of inverse modelling, the variations of the MT impedance (apparent resistivity and phase) with frequency are then used to reconstruct the variation of the electrical resistivity with depth.

For a more comprehensive introduction to the ERT method and some recent developments, we refer to Telford et al. (1990) and Binley and Kemna (2005), respectively. The MT method and the TEM method are discussed in detail in Telford et al. (1990), and Kaufman et al. (2014). Christiansen et al. (2009) give a shorter but still comprehensive introduction to the TEM method.

\section{Case studies in the Basin of Mexico}

The Basin of Mexico $\left(19^{\circ} 00^{\prime}-20^{\circ} 00^{\prime} \mathrm{N}\right.$; $98^{\circ} 00^{\prime}-$ $99^{\circ} 30^{\prime} \mathrm{W}$; 2200 m.a.s.l.) is an inter-montane basin of the Trans-Mexican Volcanic Belt. It is a continental arc formed since the Neogene, which continues to be active today (e.g. Gómez-Tuena et al., 2005; Ferrari et al., 2012). The formation of the Sierra Chichinautzin Volcanic Field since 1.2 Ma led to a hydrologic blockage in its southern part (e.g. Martin del Pozzo, 1982; Arce et al., 2013).

\section{MT setup}

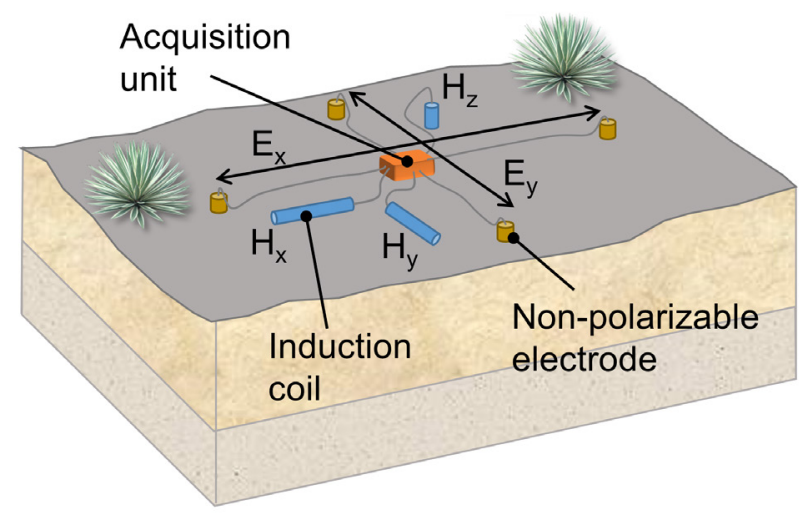

Figure 3 Schematic representation of the field setup for a MT sounding. Non-polarizing electrodes (yellowish cylinders) are used to measure the two electric field components $E_{x}$ and $E_{y^{\prime}}$ Broadband magnetic induction coils (blue cylinders) measure the two horizontal components $H_{x}$ and $H_{y}$ of the magnetic field as well as its vertical component $H_{z}$. The acquisition unit collects the time-series data of all five electromagnetic field components. 
Subsequently, a lacustrine system developed and sediments were deposited with thicknesses of up to $\sim 500 \mathrm{~m}$ in several parts of the basin (Arce $e t$ al., 2013), which preserve continuous records of the environmental history covering probably the last 300000-500000 years (Herrera-Hernández, 2011; Brown et al., 2012). Due to continuous volcanic activity in the basin and its surroundings, lacustrine sediments are interbedded with proximal and distal fall explosive deposits (Ortega-Guerrero and Newton, 1998).

\subsection{GASE I: SHALLOW EXPLORATION AT LAKE XOGHIMILCO}

\subsubsection{BACKGROUND}

The sub-basin of Xochimilco $\left(19^{\circ} 13^{\prime} \mathrm{N}, 9^{\circ} 08^{\prime}\right.$ $\mathrm{W})$ occupies the south-western extreme of the Basin of Mexico. It has a total area of $480 \mathrm{~km}^{2}$, while the last persisting remnants of the lake are limited to the chinampas area of $16 \mathrm{~km}^{2}$. Based on records available from a number of water wells lined up along the Canal de Chalco avenue (Figure 4), a general stratigraphic sequence with four main geological units can be reconstructed (CONAGUA, n.d.). The uppermost 20 to $100 \mathrm{~m}$ correspond to (1) lacustrine sediments from the Quaternary, underlain by 200 to $400 \mathrm{~m}$ of (2) Quaternary alluvial deposits, 200-300 m of (3) lacustrine deposits from the lower Pliocene and $\sim 400 \mathrm{~m}$ of (4) alluvial and volcanic deposits from the Pliocene (Ruvalcaba, 2009; and references therein). Although this sequence promises a rich sedimentary record, in comparison to other parts of the Basin of Mexico, the Xochimilco sediments have not yet received much attention for paleolimnological research.

In order to investigate the record of environmental changes preserved in the Xochimilco sediments and compare it with the fluctuations recognized in Chalco, one $47 \mathrm{~m}$ long core was planned to be collected. An earlier attempt to extract sediments at a location $2 \mathrm{~km}$ southeast of the study site using a light coring system (Usinger corer) had to be abandoned, as the corer got stuck in a strongly consolidated layer of volcanic ashes encountered at a depth of about $1 \mathrm{~m}$. Furthermore, the stratigraphic section of water well 6 BIS (see Figure 4) in immediate proximity to the study site includes a $2 \mathrm{~m}$ layer of basalt and volcanic ashes and water well $9(\sim 1 \mathrm{~km}$ southeast of the study site) reports a thick layer of volcanic ashes covering the first 20 m (CONAGUA, n.d.). To obtain preliminary information on the characteristics (presence, depth and thickness) of these consolidated materials at the drilling site, the coring campaign was preceded by a local geoelectrical survey.

\subsubsection{GEOELECTRICAL SURVEY AND DRILLING}

The first ERT profile was collected along line 1 (Figure 4) prior to the drilling campaign in May 2016. Due to more favourable surface conditions, the final drilling site was located about $25 \mathrm{~m}$ southwest of this ERT profile. In order to provide further information about subsurface heterogeneities and improve the interpretation, a second survey was conducted in June 2016 along line 2 (Figure 4 ), which is perpendicular to line 1 and closer to the actual drilling site $(<10 \mathrm{~m})$.

For both profiles, 48 stainless steel electrodes were pushed into the ground with a regular spacing of 5 $\mathrm{m}$ between the electrodes, resulting in total profile lengths of $235 \mathrm{~m}$. The measurements were carried out using a Syscal Pro Switch 48 device (Iris Instruments), which allows for an automatic collection of tomographic data sets. The profiles were measured applying dipole-dipole, Wenner and pole-dipole configurations. For the pole-dipole measurements, the first electrodes were relocated at $200 \mathrm{~m}$ distance from the profiles (see Figure 4) to serve as remote (or 'infinite') poles. The length of the profiles and the selection of different geometrical configurations aimed at a maximum depth of investigation of approximately $70 \mathrm{~m}$. Data inversion was carried out using the software RES2DINV (Loke and Barker, 1995), which is based on a smoothness-constrained least-squares algorithm. Outliers in the data were defined as those measurements with anomalously low $\left(\rho_{\mathrm{a}}<1 \Omega \mathrm{m}\right)$ or high $\left(\rho_{\mathrm{a}}>30 \Omega \mathrm{m}\right)$ apparent resistivities. Using this 


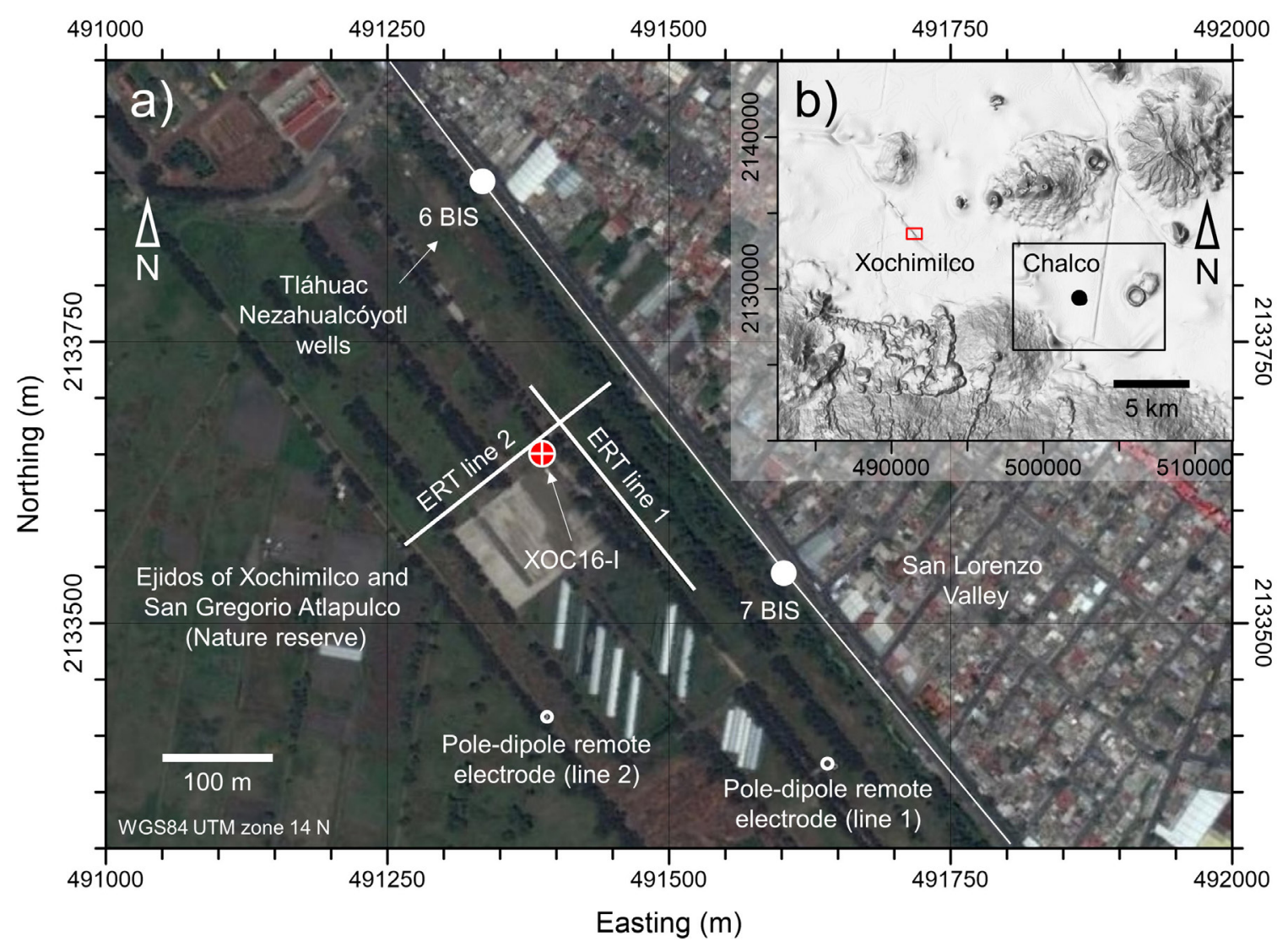

Figure 4 a) Layout of the geoelectrical survey, the drilling site of XOC16-1 (red circle), and the Tláhuac-Nezahualcóyotl water wells in the plain of Lake Xochimilco (white solid circles). b) Localization of the study area (red rectangle) in the south-eastern part of the Basin of Mexico (image data: Google and DigitalGlobe, 2016a, shaded relieve: INEGI, 2016).

criterion, $45 \%$ of the 992 dipole-dipole readings, $8 \%$ of the 360 Wenner readings, and $8 \%$ of the 1226 pole-dipole readings were removed from the data prior to the inversion.

The drilling was contracted to tgc Geotecnia S.A. de C.V., which used a drive-sampling technique to retrieve an undisturbed 4 inch sediment core down to a maximum depth of $47 \mathrm{~m}$ below the ground surface (in the following called 'XOC16-I'). Within the layer of indurated volcanic ash, which was encountered between $\sim 1.5 \mathrm{~m}$ and $\sim 14.5 \mathrm{~m}$, sediment samples were recovered by percussion drilling. Samples of the uppermost $\sim 1.5 \mathrm{~m}$ of top soil and lacustrine sediments, which could not be obtained with the drive sampler, were later collected from a shallow trench. The laboratory analysis of the sediment core and samples is still in progress and to date a preliminary stratigraphic description is available.

\subsubsection{RESULTS AND INTERPRETATION}

While the inverted resistivity models of all measured configurations (i.e. dipole-dipole, Wenner and pole-dipole) contained practically identical information in the shallow parts of both sections, their maximum depths of investigation varied largely (dipole-dipole: $20 \mathrm{~m}$, Wenner: $40 \mathrm{~m}$, pole-dipole: $70 \mathrm{~m}$ ). As mentioned above, the depth of investigation mainly depends on the geometrical characteristics of the electrode configurations, but can decrease significantly in highly conductive materials (as the case of saturated fine-grained lacustrine sediments). Therefore, the inverted re- 


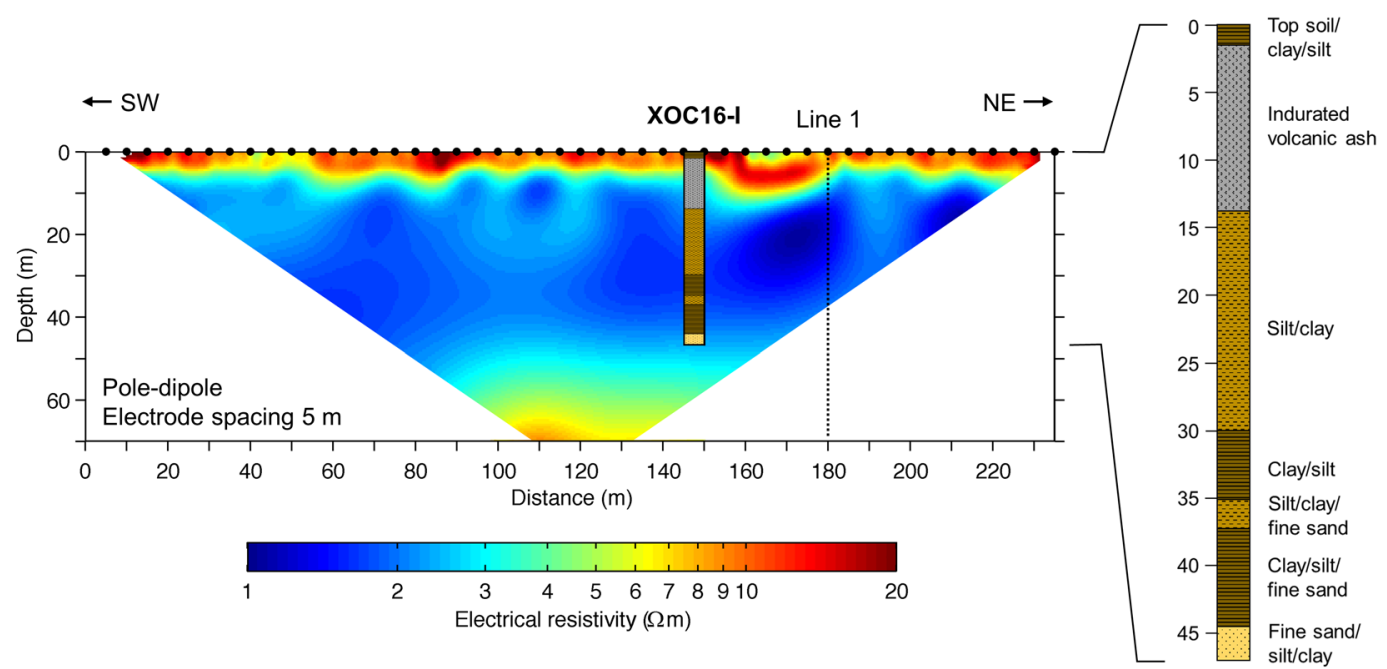

Figure 5 Left: Inverted electrical resistivity models for pole-dipole measurements on ERT line 2. Black solid circles at the surface indicate electrode positions. Right: Preliminary stratigraphy of Lake Xochimilco Core XOC16-I.

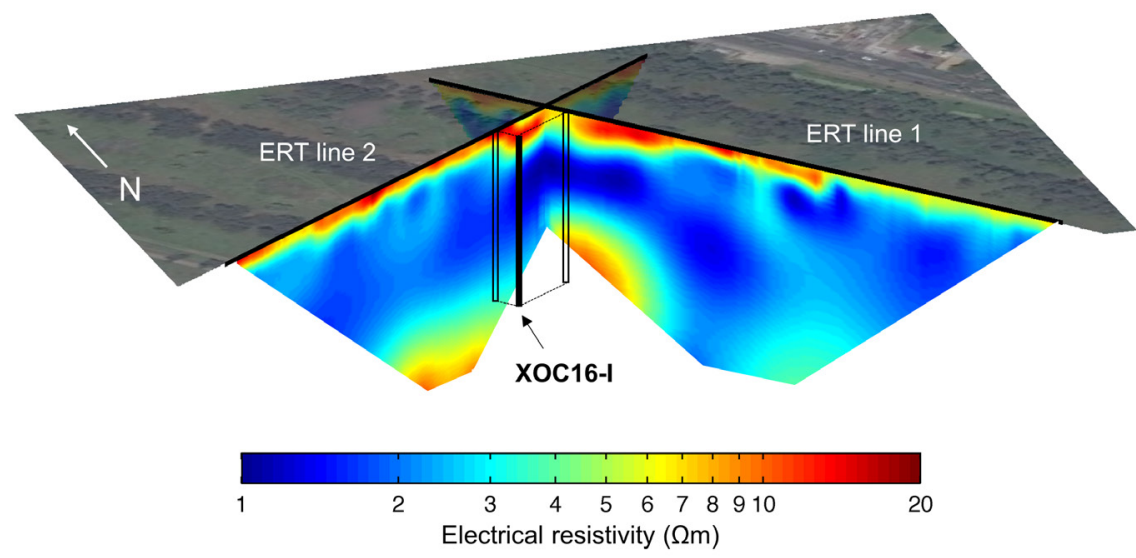

Figure 6 3D-visualization of the inverted electrical resistivity models for pole-dipole measurements on both ERT lines and the relative location of Lake Xochimilco Core XOC16-I. Vertical exaggeration $1 \mathrm{x}$

sistivity models of the two ERT lines shown in Figures 5 and 6 stem from pole-dipole measurements only.

All presented models consistently show three main geoelectrical units forming - with few exceptions - laterally continuous layers. The first unit extends from the surface to depths between 5 and $10 \mathrm{~m}$ and is characterized by relatively large resistivities between 3 and $20 \Omega \mathrm{m}$ (warm colours). The second unit is easily distinguished from the first one by its much lower resistivities of 1 to $3 \Omega \mathrm{m}$ (cold colours). A third unit with slightly increased resis- tivities between 3 and $10 \Omega \mathrm{m}$ occupies the lowest part of the geoelectrical sections and can be found from depths between $30 \mathrm{~m}$ (north-western part of line 1) and $45 \mathrm{~m}$ (line 2). In the south-eastern part of line 1, this more resistive unit cannot be distinguished clearly from the intermediate conductive layer.

The preliminary stratigraphic column of core XOC16-I (Figure 6) offers a straight-forward interpretation of the differentiation into three geoelectrical units. The uppermost $\sim 1.5 \mathrm{~m}$ of top soil, clayey and silty material, which would be expected 
to have low resistivities, are too thin to be resolved using an electrode spacing of $5 \mathrm{~m}$. The layer of consolidated coarse- to medium-grained volcanic ash, which extends from $1.5 \mathrm{~m}$ to $14.5 \mathrm{~m}$, roughly correlates with the extensions of the shallow resistive unit $(>10 \Omega \mathrm{m})$. Beneath the ash layer, the stratigraphy is quite homogenous and corresponds to lacustrine sediments with textures varying between clay and silt that explain the low resistivity values at these intermediate depths $(<3 \Omega \mathrm{m})$. The increase of the content of fine to medium sand in the lacustrine sediments and the sand encountered on the last $2.5 \mathrm{~m}$ of the core can explain the increase of the electrical resistivity at depth. The increase of the resistivity below the maximum depth of the drilling at $47 \mathrm{~m}$, might indicate a continued increase of the fractions of coarser material in the sediments. This hypothesis can further be supported by the presence of alluvial and volcanic deposits (silt, sand, gravel and volcanic ashes) encountered between 40 and $70 \mathrm{~m}$ in the nearby water well 6 BIS (CONAGUA, n.d.).

Inconsistencies observed in the resistivity imaging results (e.g. regarding the deep resistive unit) and the difficulties to accurately delineate the contact between the indurated volcanic ash and the lacustrine sediments at $\sim 14 \mathrm{~m}$ might be attributed to $3 \mathrm{D}$ effects in the acquisition and modelling of $2 \mathrm{D}$ resistivity models. Furthermore, the drilling is located at about $10 \mathrm{~m}$ from line 2 and the shape of the shallow resistive layer - particularly between 150 and $180 \mathrm{~m}$ along the profile direction - indicates a large spatial variability of the thickness of this layer in the immediate surroundings of XOC16-I.

Although the presented interpretation of the electrical units might still be improved, imaging results such as those presented in Figure 5 and Figure 6 reveal the possibility to gain valuable information on lithological contacts prior to the drilling. In particular, the electrical results (1) suggested that drilling through the thick ash layer was warranted in order to reach the deeper lacustrine sediment layers, the presence of which was clear from the high conductivities observed in the geoelectrical section and (2) aid the planning of future drilling campaigns taking into consideration the deep resistive layer likely associated with alluvial and volcanic sediments.

\subsection{GASE II: DEEP EXPLORATION AT LAKE GHALGO}

\subsubsection{BACKGROUND}

In comparison to the sub-basin of Xochimilco, for which only scarce information on the shallow sedimentary fill is available, the sub-basin of Chalco $\left(19^{\circ} 15^{\prime} \mathrm{N}, 98^{\circ} 58^{\prime} \mathrm{W}\right)$ has been studied extensively during the last decades. Basin-scale geophysical data is available from a series of studies summarized by Campos-Enríquez et al. (1997). In particular, from gravimetric data analysed by these authors and the stratigraphic record from the deep $(3 \mathrm{~km})$ well drilled by PEMEX in Tulyehualco (Pérez-Cruz, 1988), a depth to the volcanic basement of 300 to $500 \mathrm{~m}$ can be inferred for the central part of the sub-basin of Chalco. High-resolution stratigraphic records and age models of the uppermost $122 \mathrm{~m}$ of sedimentary fill are available from earlier paleolimnological drillings (e.g. Herrera-Hernández, 2011 ; Lozano-García et al., 2015; Ortega-Guerrero et al., 2015). Based on this information, an age of at least $\sim 300000-500000$ years of Lake Chalco's sediments can be estimated (Herrera-Hernández, 2011; Brown et al., 2012), which makes the latter a unique record of climate and environmental history.

Based on MT sounding results from the northern part of the lacustrine plane and the stratigraphic records of the Santa Catarina-Mixquic water wells (see Figure 7), Chouteau et al. (1994) established a general geological section across the Chalco sub-basin. Based on this section, the thickness of the lacustrine sediment cover reaches its maximum thickness of $\sim 200 \mathrm{~m}$ at the southern end of the line of wells indicating a suitable location for paleolimnological drilling. According to Chouteau et al. (1994), these lacustrine sediments are underlain by $\sim 150 \mathrm{~m}$ of granular volcanic material and another $\sim 150 \mathrm{~m}$ of fractured volcanic rocks (basalt); solid (unfractured) volcanic rock is inferred 
to underlie the entire sequence at a depth of $\sim 500$ $\mathrm{m}$. Although this model has later been adapted by a number of other studies (e.g. Krivochieva and Chouteau, 2003), it is important to recall that the stratigraphic records of the Santa Catarina-Mixquic water wells are limited to the upper $400 \mathrm{~m}$ and most of the available geophysical data (i.e. vertical electrical soundings, seismic refraction) also does not cover larger depths with the gravity data being the only exception (Campos-Enríquez et al., 1997 and references therein).

In consequence, Brown et al. (2012) state a possible insufficiency of the existing geophysical data for the selection of a suitable site for a planned $500 \mathrm{~m}$ drilling to recover the sedimentary record of the sub-basin of Chalco (Lozano-García et al., 2017). In order to fill this gap, a recent seismic survey (Vergara-Huerta, 2015) used the horizontal-to-vertical (H/V) ambient-noise method to provide a new estimate of the depth to bedrock in the surroundings of the later drilling site. However, the results of this study indicate a much smaller thickness of approximately 100-150 m of lacustrine sediments. Because combined MT and TEM surveys helped to constrain the geometry of the geological units down to at least $800 \mathrm{~m}$ (Chouteau et al., 1994; Krivochieva and Chouteau, 2003), one MT and several TEM soundings were measured shortly before the start of the MexiDrill campaign in April 2016 (Lozano-García et al., 2017) to provide additional geophysical information.

\subsubsection{ELECTROMAGNETIC SOUNDINGS}

It is worth mentioning that the MexiDrill site coincides with the southern end of the line of Santa Catarina-Mixquic wells (Figure 7), where it is located on a small artificial-fill platform in the new Lake Chalco and in a few meters from the medium-voltage power line that supplies the wells. In order to provide enough space to extend the loops for the TEM sounding and reduce electromagnetic noise and coupling in both TEM and MT data, the sounding sites were located roughly 700 $\mathrm{m}$ west of the drilling site (Figure 7).

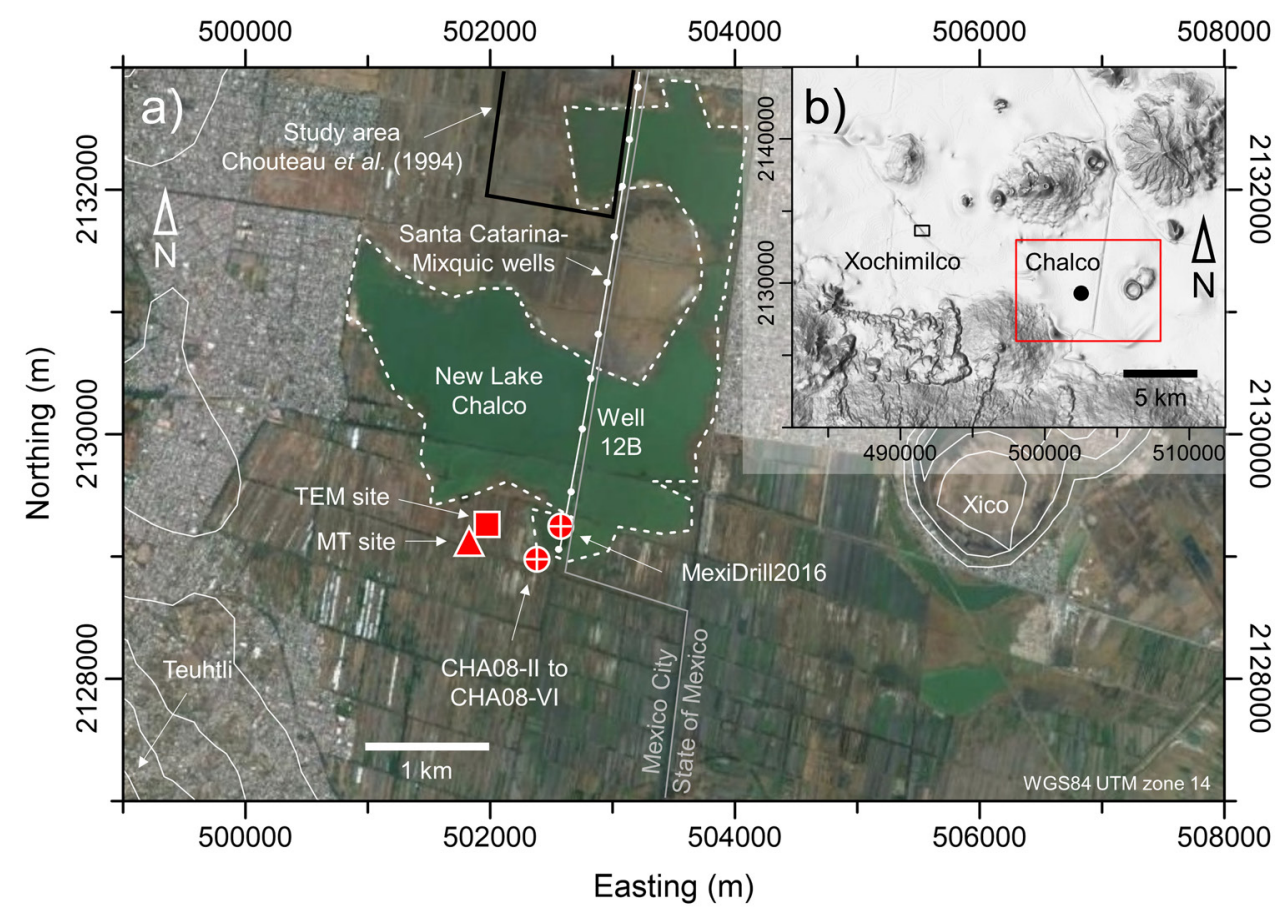

Figure 7 a) Map of the study area at Lake Chalco. Red symbols mark the locations of the geophysical TEM (square) and MT (triangle) sounding sites, the scientific drillings CHA08-II through CHA08-VI and the MexiDrill site. b) Localization of the study area (red rectangle) in the southernmost part of the Basin of Mexico (image data: Google and DigitalGlobe, 2016b, shaded relieve: INEGI, 2016), 
a) Apparent resistivity

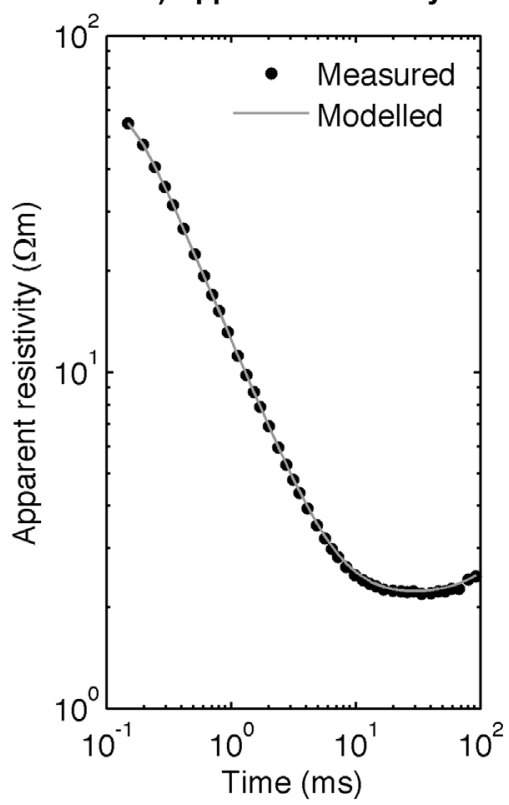

b) Resistivity models

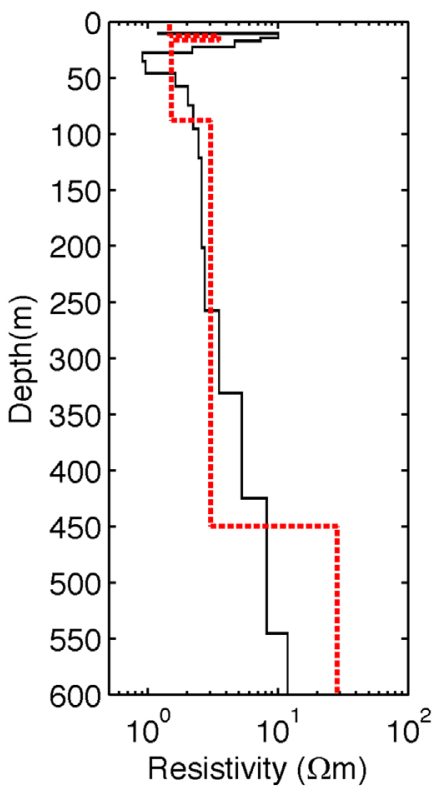

Figure 8 TEM sounding measured with a 300 m x 300 m loop. a) Measured (black circles) and calculated (grey line) apparent resistivity as a function of time. b) Inverted smooth (black solid line) and layered-earth (red dashed line) electrical resistivity models.

At the TEM site (Figure 7), two single-loop soundings were collected using $150 \mathrm{~m} \times 150 \mathrm{~m}$ and 300 m x 300 m square loops, respectively. The Monex GeoScope TerraTEM system was used for both soundings. Transmitted currents were $\sim 6$ A $(150$ $\mathrm{m} \times 150 \mathrm{~m}$ loop$)$ and $\sim 1.5 \mathrm{~A}(300 \mathrm{~m} \times 300 \mathrm{~m}$ loop) in both cases yielding a magnetic moment of $\sim 135000 \mathrm{Am}^{2}$. Transient data was measured in the time range from 0.1 to $100 \mathrm{~ms}$ after current switch off using 43 logarithmically spaced time windows. All data were acquired with an internal notch filter activated that suppresses the effect of power-line noise $(60 \mathrm{~Hz})$. For each sounding 250 individual transients were recorded and averaged. The good data quality observed for all measured times (see apparent resistivity in Figure 8) did not require any outlier removal or further processing. Individual inverse modelling of both soundings was done using the software WinGLink (Geosystem). This software does a one-dimensional inversion of the measured transient data in terms of a smooth resistivity model (Constable et al., 1987). Based on the inflections of the smooth model a simple layered-earth model can then be adjusted in a second step. Figure 8 illustrates the smooth (black solid line) and the layered-earth (red dashed line) model adjusted to the measured apparent resistivity curve (black circles) of the $300 \mathrm{~m} \times 300 \mathrm{~m}$ sounding.

The MT sounding data was acquired using a Metronix ADU-07e system. Horizontal electric fields $\left(E_{x}, E_{y}\right)$ were measured along two perpendicular $40 \mathrm{~m}$ long dipoles using non-polarizing lead-lead chloride $(\mathrm{Pb}-\mathrm{PbCl})$ electrodes. Two perpendicular horizontal components of the magnetic field $\left(H_{x}, H_{y}\right.$, parallel to the electric dipoles) as well as its vertical component $\left(H_{z}\right)$ were measured with Metronix MFS-06e low-noise broadband induction coils. Data were acquired in five frequency bands: $32768 \mathrm{~Hz}$ (acquisition time $1 \mathrm{~min}$ ), 16834 $\mathrm{Hz}$ (2 $\mathrm{min}), 8192 \mathrm{~Hz}$ (5 min), $4096 \mathrm{~Hz}$ (15 min), and $128 \mathrm{~Hz}$ (4 hours). However, due to a poor data quality in the high-frequencies, only data of the three low-frequency bands (8192, 4096, and 128 $\mathrm{Hz}$ ) was used for processing. 
a) Apparent resistivity

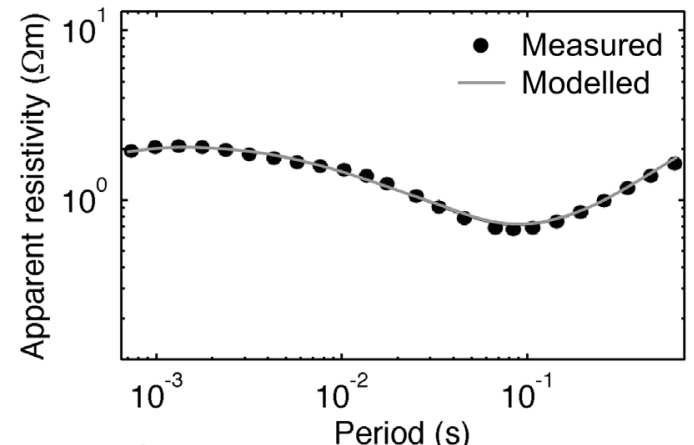

b) Phase

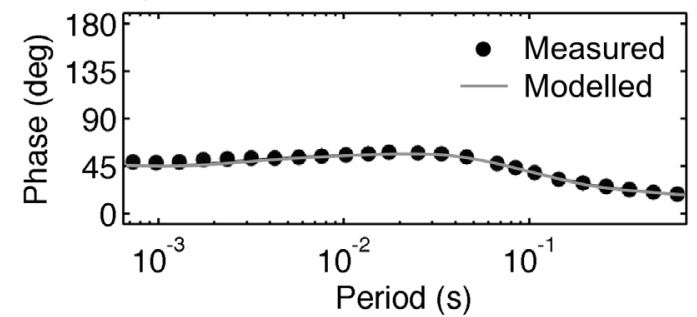

c) Resistivity models

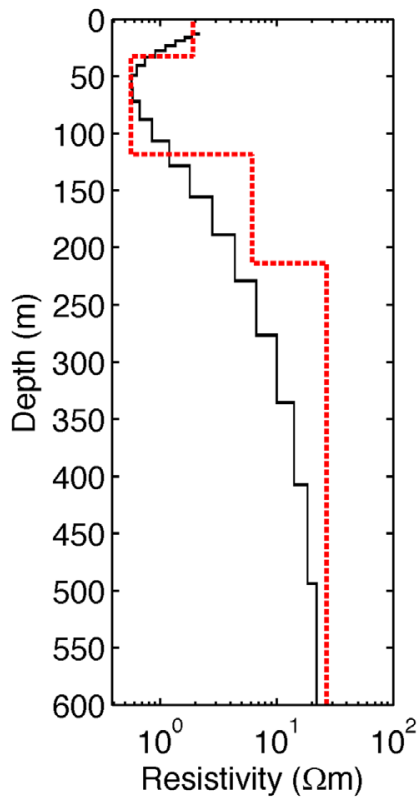

Figure 9 a) Apparent resistivity and b) phase of the MT sounding data (invariant mode). Measured (solid circles) and modelled (grey line) are illustrated. c) Inverted smooth (black solid line) and layered-earth (dashed red line) electrical resistivity models.

For the correction of a possible static shift introduced by shallow resistivity anomalies (e.g. Pellerin and Hohmann, 1990), a small $25 \mathrm{~m}$ x $25 \mathrm{~m}$ single-loop TEM sounding was collected at the MT site using a TEM-FAST 48 system (AEMR). Injected current was 1 A yielding a magnetic moment of $625 \mathrm{Am}^{2}$. Transient data were acquired from $\sim 0.006$ to $13 \mathrm{~ms}$. Other than for the static-shift correction, this TEM sounding was processed and interpreted in a similar manner as the other TEM data, because due to the instrument's characteristics the TEM-FAST data usually yields a better resolution of shallow resistivity variations. The recorded MT time-series are processed using the robust algorithms implemented in the software ProcMT (Friedrichs, 2016) in order to estimate scalar apparent resistivities and phases as a function of frequency (Figure 9). This apparent MT impedance data is then modelled using the smoothness-constraint inversion algorithm included in the MT module of the WinGLink software (Geosystem). As in the case of TEM modelling, subsequently the resulting smooth resistivity model is used to adjust a simple layered-earth model. The software also allows correction of the static shift in the apparent impedance data based on the collocated $25 \mathrm{~m}$ x $25 \mathrm{~m}$ TEM sounding. Due to polarization of the measured data observed at long periods (low frequencies), data from periods $>1.4 \mathrm{~s}$ were excluded prior to inversion. Figure 9 illustrates the smooth (black solid line) and the layered-earth (red dashed line) model adjusted to the measured apparent resistivity and phases (black squares) of the MT sounding.

\subsubsection{RESULTS AND INTERPRETATION}

The upper $122 \mathrm{~m}$ of the electric resistivity models obtained from the TEM soundings using 25 and $150 \mathrm{~m}$ loops are presented in Figure 10. Both soundings consistently show the presence of three electrostratigraphic main units; (1) a shallow unit with resistivities of up to $5 \Omega \mathrm{m}$ that extends from the surface down to depths between 5 and $15 \mathrm{~m}$, (2) a highly conductive unit with resistivities be- 


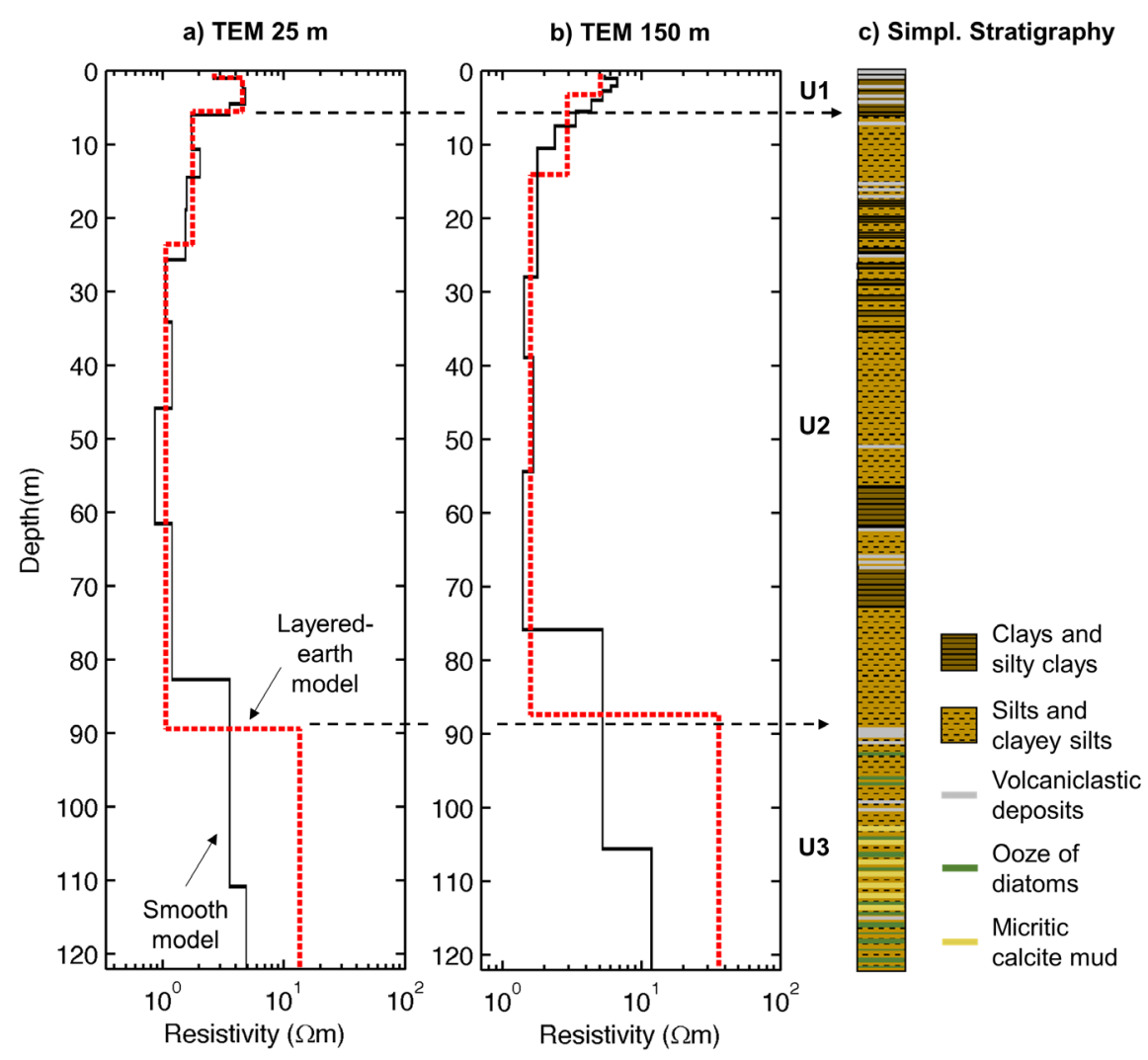

Figure 10 Left and centre: Upper $122 \mathrm{~m}$ of the electrical resistivity models obtained from TEM soundings with a) $25 \mathrm{~m} \times 25 \mathrm{~m}$ loop and b) $50 \mathrm{~m} \times 50 \mathrm{~m}$ loop. Smooth models (black solid lines) and layered-earth models (dashed red lines) are illustrated. Right: Simplified stratigraphic record reconstructed from cores CHA08-II through CHA08-VI (modified from Herrera-Hernández, 201 1).

tween 1 and $2 \Omega \mathrm{m}$, the lower limit of which is located around $90 \mathrm{~m}$, and (3) a more resistive unit $(15-30 \Omega \mathrm{m})$ at the bottom. Although the nominal investigation depth of the $150 \mathrm{~m}$ loop soundings was larger $(\sim 300 \mathrm{~m})$, no significant resistivity contrasts were observed at greater depths.

The inferred resistivity variations can be attributed to lithological changes observed along the $122 \mathrm{~m}$ long stratigraphic master section (Figure 10) reconstructed from cores CHA08-II through CHA08-VI (Herrera-Hernández, 2011; Ortega-Guerrero et al., 2015) retrieved earlier at a nearby site (Figure 7). The relatively high resistivities of the shallow unit seem to be related to numerous strata of volcanic ash interbedded with lacustrine sediments. The presence of these volcaniclastic deposits decreases significantly below $5 \mathrm{~m}$, which coincides with the decrease of resistivity observed in the high-resolution sounding (TEM-FAST, 25 $\mathrm{m}$ loop). Consequently, the low resistivities of the second unit could be related to the fine-grained lacustrine sediments, which are rarely interrupted by volcaniclastic deposits down to a depth of 90 $\mathrm{m}$. Resistivities in this unit might additionally be reduced by saline pore-water (e.g. Chouteau et al., 1994; Campos-Enríquez et al., 1997). The increase of resistivity around $90 \mathrm{~m}$ again coincides with an increase of the frequency of interbedded volcaniclastic deposits. Interestingly, at the same depth and below, lacustrine and volcaniclastic sediments also show a significant increase in the content of diatom oozes and intercalated layers of micritic calcite mud (Herrera-Hernández, 2011).

The electrical resistivity models inverted from the $300 \mathrm{~m}$ loop TEM sounding and the MT sounding are presented in Figure 11. Due to the size of 
a) TEM $300 \mathrm{~m}$

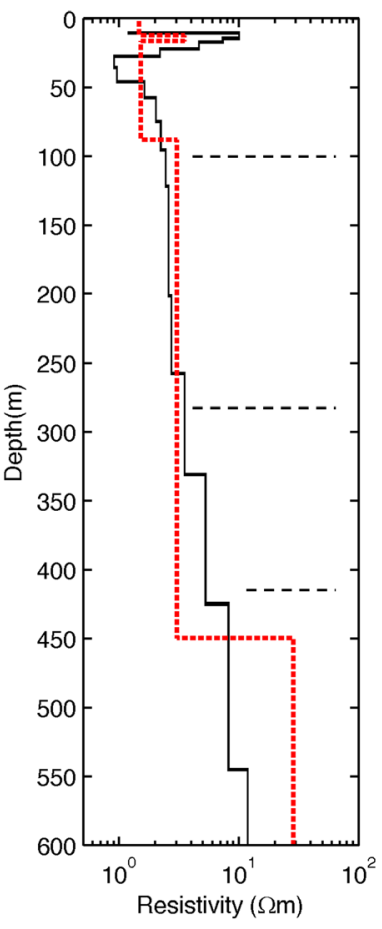

b) MT

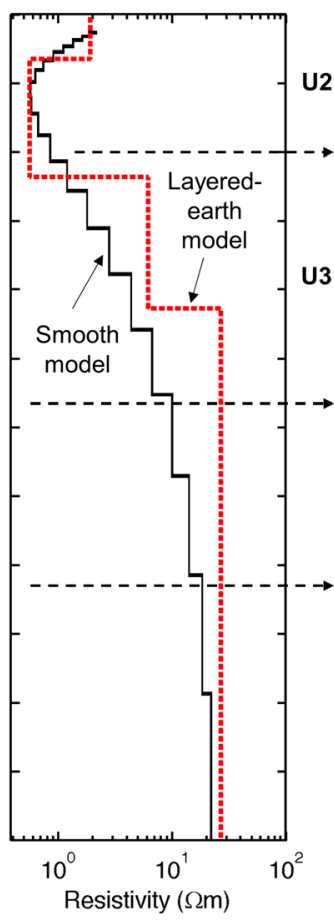

c) Mag. Susc.

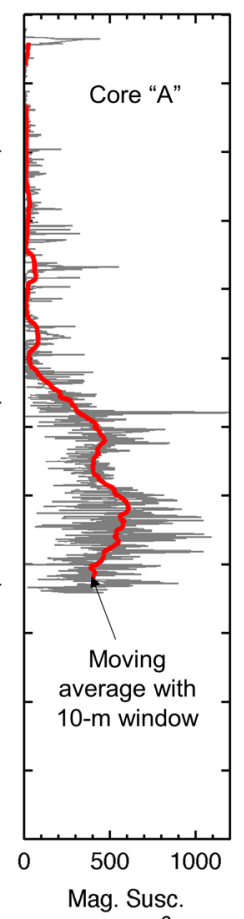

d) Prelim. Stratigraphy

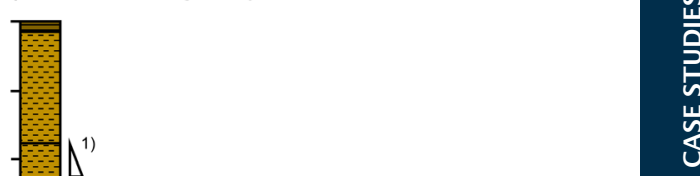

Figure 11 Inverted resistivity models obtained from a) the TEM sounding with $300 \mathrm{~m} \times 300 \mathrm{~m}$ loop and b) the MT sounding. Smooth models (black solid lines) and layered-earth models (dashed red lines) are illustrated. c) Magnetic susceptibility scan (thin grey line) of MexiDrill core "A" (Lozano-García et al., 2017), moving average with $10 \mathrm{~m}$ window width (thick red line) and d) preliminary stratigraphy of the MexiDrill drilling.

the loop in the case of the TEM sounding and the elimination of the high-frequency bands from the MT data, the shallow resistive unit is not resolved by either of these two soundings. The bottom of the conductive unit (U2), however, correlates with a resistivity increase between $90 \mathrm{~m}$ (TEM) and 120 m (MT) observed in the layered-earth models. At greater depths, the smooth models of both soundings show a continuously increasing resistivity to $30 \Omega \mathrm{m}(\mathrm{TEM})$ and $20 \Omega \mathrm{m}(\mathrm{MT})$ down to the maximum displayed depth of $600 \mathrm{~m}$. The boundaries of the layered-earth models at $\sim 450 \mathrm{~m}$ (TEM) and $\sim 215 \mathrm{~m}$ (MT) are somewhat arbitrary and not well defined. The inconsistency among TEM and MT at depth is most probably related to the effect of cultural noise from sources located in the nearby urban areas (e.g. Szarka, 1988).

Along with the resistivity models, Figure 11 shows the preliminary magnetic susceptibility scan of core " $\mathrm{A}$ " and the main lithological contacts observed during drilling operations (Lozano-García et al., 2017). Besides a peak at approximately $20 \mathrm{~m}$ depth, the magnetic susceptibility shows low values from the surface down to 90-100 m reflecting the low amount of volcaniclastic deposits within the lacustrine sediments. Between 100 and 250 $m$ depth, we observe a large number of isolated susceptibility peaks indicating an increased presence of interbedded volcaniclastic deposits. Between 250 and $300 \mathrm{~m}$ the magnetic susceptibility increases significantly, marking the transition from lacustrine sediments to practically pure volcaniclastic deposits below $\sim 300 \mathrm{~m}$. Susceptibility data of core "A" was only measured down to $410 \mathrm{~m}$, where the top of a thick sequence of basalt flows was encountered. Basalts are present down to a 
depth of at least $\sim 512 \mathrm{~m}$, were the deepest of the four MexiDrill cores $(520 \mathrm{~m})$ detected hydrothermally altered alluvial sediments.

The comparison of the resistivity models with the magnetic susceptibility data supports our interpretation of the resistivity increase around 90-100 m correlated with the accumulation of volcaniclastic deposits. The continued increase with depth of this less-conductive material within the lacustrine sediments can also explain the smooth variation of the resistivity at greater depths. Unfortunately, the gradual character of this increase masks the top of the pure volcaniclastic deposits below $\sim 300 \mathrm{~m}$, which is not resolved by our resistivity soundings. Neither do the soundings detect the limit between volcaniclastic material and basalt at $\sim 410 \mathrm{~m}$.

Despite of the limited contrast of the resistivity models at depth (>400 m), the continuous increase of electric resistivities below $400 \mathrm{~m}$ depth strongly indicates that no significant layers of lacustrine conductive sediments could be expected at greater depths. This information provided by TEM and MT sounding results, together with an analysis of available geological data, led to the decision to terminate the first two drill cores slightly below the upper limit of the basalt layer. Only after having retrieved enough lacustrine sediments, the last of the three deep drill cores was continued beyond $400 \mathrm{~m}$ depth. Although the last $100 \mathrm{~m}$ of basaltic rock and rubble do not explicitly contribute to paleolimnological research, their analysis will be valuable for a deeper understanding of the geological evolution of the sub-basin of Chalco.

\section{Discussion and Conclusions}

In both presented case studies, a good correlation between electrical resistivity models and stratigraphic sequences from collocated drill cores was observed. In the case of Lake Xochimilco, two ERT sections permitted to infer the presence of lacustrine sediments below a thick unit of indurated volcanic ash $(\sim 14 \mathrm{~m})$, improving the outcome of the drilling campaign. As the investigation depth required for the planning of the collection of a $\sim 50 \mathrm{~m}$ sediment core was limited to $<100 \mathrm{~m}$, the ERT method was well suited to gain a spatially continuous image of the subsurface conditions. For deeper explorations, however, the required length of the electrode array makes this method less efficient than TEM or MT soundings.

In the case of Lake Chalco, the resistivity variation obtained from TEM and MT soundings clearly indicated a partitioning of the sediment fill into different units. However, the limited individual thicknesses of the alternating deposits of lacustrine sediments and volcaniclastic material were too small to be resolved at depths of tens to hundreds of meters and in particular the gradual increase of the fraction of volcaniclastic deposits with depth hampered the reconstruction of an exact sediment thickness. While the resistivity models reflected this transition very well, the gradual increase masked the actual layer boundaries, which could have been difficult to interpret without additional data from complementary geophysical data or drill cores available. Nevertheless, it should be noted that the mentioned complexity of the studied geological sequence puts a challenge on most geophysical exploration methods. In this study, the main contribution of the electromagnetic soundings was the important conclusion that no significant lacustrine sediment layers were to be expected at depths $>400 \mathrm{~m}$ as indicated by the continued increase of electric resistivities.

For less complex environments, where (pure) lacustrine sediments are in direct contact with a consolidated and low-permeability basement, we can infer that resistivity models would be suited to map this contact. Colombero et al. (2014), for instance, used ERT surveys to reconstruct the geological evolution of a glacial lake in Italy and Hautot et al. (2006) used MT soundings to infer the structure of a Mesozoic basin beneath Lake Tana in Ethiopia. The latter can also serve as an interesting example for an EM survey that combines the 1D models of more than one MT sounding to reconstruct a basin-scale geological section. 
Besides the increased resistivity contrast with bedrock material, the generally high conductivity of fine-grained lacustrine sediments also favours another respect. Although conductive environments typically reduce the expected investigation depth of electromagnetic exploration, they also reduce the influence of cultural noise (e.g. from power lines, etc.) and make TEM and MT studies feasible even in or close to urban areas (e.g. Krivochieva et al., 2003).

In this study, we strictly present results from terrestrial measurements. However, as paleolimnological research is certainly not limited to (near) desiccated lake basins, it is important to clarify that all three methods presented can also be applied on existing lakes. We refer to Colombero et al. (2014) for an interesting application of ERT on a glacial lake in Italy, Mollidor et al. (2013) for a TEM survey on a crater lake in Germany, and Bastani et al. (2015) for a boat-towed radio-frequency MT survey on Lake Mälaren in Sweden.

\section{Acknowledgements}

We gratefully acknowledge financial support for the presented case studies provided by the UNAM (DGAPA-PAPIIT-IV100215: "Cambio climático y medio ambiente en la historia del Lago de Chalco", and DGAPA-PAPIIT-IN107416-2: Paleoambientes del Pleistoceno tardío en la cuenca de Xochimilco"), as well as the National Science Foundation (NSF 1551311 MexiDrill: The Basin of Mexico Drilling Program). Matthias Bücker's participation in this study was partly funded by a scholarship awarded by the TU-Wien. We thank Sergio Rodríguez Elizarrarás from the Instituto de Geología (IGL) of the UNAM, who kindly provided the Syscal Pro Switch measuring system. Special thanks to Elena Centeno (IGL) and the staff from Instituto de Geología and Instituto de Geofisica, UNAM for their support. Cecilia Caballero, Ana María Soler and Susana Sosa helped with the laboratory tasks. Rafael Cossío assisted during the geoelectrical field work in Xochimilco. We acknowledge the many other individuals, especially students, local authorities, and personnel of the Ejido Santiago Tulyehualco, without whose help and cooperation the realization of the field surveys would not have been possible. Furthermore, we thank all Mexi-Drill scientific team members for their support of the ICDP drilling campaign at Lake Chalco. Silvana Geuna and one anonymous reviewer provided valuable comments that helped to improve this manuscript.

\section{References}

Arce, J., Layer, P., Lassiter, J., Benowitz, J., Macías, J., Ramírez-Espinosa, J., 2013, 40Ar/39Ar dating, geochemistry, and isotopic analyses of the Quaternary Chichinautzin Volcanic Field, south of Mexico City: implications for timing, eruption rate, and distribution of volcanism: Bulletin of Volcanology, 75(12), $1-25$.

Archie, G.E., 1942, The electrical resistivity log as an aid in determining some reservoir characteristics: Transactions of the AIME, 146(1), 54-62.

Bastani, M., Persson, L., Mehta, S., Malehmir, A., 2015, Boat-towed radio-magnetotellurics - A new technique and case study from the city of Stockholm: Geophysics, 80(6), B193-B10.

Binley, A., Kemna, A., 2005, DG resistivity and induced polarization methods, in Rubin, Y., Hubbard, S.S. (eds.), Hydrogeophysics: Dordrecht, Springer Netherlands, 129-156.

Brown, E.T., Werne, J.P., Lozano-García, S., Caballero, M., Ortega-Guerrero, B., CabralCano, E., Valero-Garces, B.L., Schwalb, A., Arciniega-Ceballos, A., 2012, Scientific drilling in the basin of Mexico to evaluate climate history, hydrological resources, and seismic and volcanic hazards: Scientific Drilling, 14, 72-75. 
Campos-Enríquez, J.O., Delgado-Rodríguez, O., Chávez-Segura, R., Gómez-Contreras, P., Flores-Márquez, E.L., Birch, F.S., 1997, The subsurface structure of the Chalco sub-basin (Mexico City) inferred from geophysical data: Geophysics, 62(1), 23-35.

Chouteau, M., Krivochieva, S., Castillo, R.R., Moran, T.G., Jouanne, V., 1994, Study of the Santa Catarina aquifer system (Mexico Basin) using magnetotelluric soundings: Journal of Applied Geophysics, 31(1-4), 85-106.

Christiansen, A.V., Auken, E., Sørensen, K., 2009, The transient electromagnetic method, in Kirsch, R. (ed.), Groundwater Geophysics: A tool for hydrogeology: Berlin/Heidelberg, Germany, Springer, 179-226.

Cohen, A.S., 2003, Paleolimnology: the history and evolution of lake systems: New York, USA, Oxford University Press, 528 p.

Colombero, G., Comina, C., Gianotti, F., Sambuelli, L., 2014, Waterborne and on-land electrical surveys to suggest the geological evolution of a glacial lake in NW Italy: Journal of Applied Geophysics, 105, 191-202.

Comisión Nacional del Agua (CONAGUA), n.d., [unpublished stratigraphic columns of water wells of the Ramal Tláhuac Nezahualcóyotl], Mexico City, Mexico.

Constable, S.C., Parker, R.L., Constable, C.G., 1987, Occam's inversion: A practical algorithm for generating smooth models from EM sounding data: Geophysics, 52, 289-300.

Davy, B., 1992, Seismic reflection profiling on southern lake rotorua-evidence for gascharged lakefloor sediments: Geothermics, 21(1), 97-108.

Dean, W.E., 2010, Recent advances in global lake coring hold promise for global change research in paleolimnology: Journal of Paleolimnology, 44(2), 741-743.

Ferrari, L., Orozco-Esquivel, M.T., Manea, V., Manea, M., 2012, The dynamic history of the Trans-Mexican Volcanic Belt and the
Mexico subduction zone: Tectonophysics, 522-523, 122-149.

Friedrichs, B., 2016, ProcMT Manual online, Braunschweig, Germany, Metronix GmbH, available from <http://www.geo-metronix.de/ procmt_html/index.html>, retrieved 10 Sep 2016.

Fritz, S.C., 1996, Paleolimnological records of climatic change in North America: Limnology and Oceanography, 41(5), 882-889.

Gómez-Tuena, A., Esquivel, M.T.O., Ferrari, L., 2005, Petrogénesis ígnea de la faja volcánica transmexicana: Boletín de la Sociedad Geológica Mexicana, 57(3), 227-283.

Google and DigitalGlobe, 2016a, Vivero Nezahualcóyotl and surrounding areas, viewed 1 September 2016 using Google Earth version 7.1.7.2606.

Google and DigitalGlobe, 2016b, Lake Chalco and surrounding areas, viewed 8 September 2016 using GoogleEarth version 7.1.7.2606.

Hautot, S., Whaler, K., Gebru, W., Desissa, M., 2006, The structure of a Mesozoic basin beneath the Lake Tana area, Ethiopia, revealed by magnetotelluric imaging: Journal of African Earth Sciences, 44(3), 331-338.

Herrera-Hernández, D., 2011, Estratigrafía y análisis de facies de los sedimentos lacustres del Cuaternario tardío de la cuenca de Chalco, México: Mexico City, Mexico, Universidad Nacional Autónoma de México, Instituto de Geofísica, MSc Thesis, $122 \mathrm{p}$.

INEGI, 2016, Xochimilco-Chalco sub-basin, retrieved 1 September 2016 from < http:// www.inegi.org.mx/geo/contenidos/ datosrelieve/continental/descarga.aspx>

Kaufman, A.A., Alekseev, D., Oristaglio, M., 2014, Principles of electromagnetic methods in surface geophysics (Vol. 45): Amsterdam, Elsevier, $770 \mathrm{p}$.

Krivochieva, S., Chouteau, M., 2003, Integrating TDEM and MT methods for characterization and delineation of the Santa Catarina aquifer (Chalco Sub-Basin, Mexico): Journal of Applied Geophysics, 52(1), 23-43. 
Kutterolf, S., Schindlbeck, J.C., Anselmetti, F.S., Ariztegui, D., Brenner, M., Curtis, J., Schmid, D., Hodell, D.A., Mueller, A., Pérez, L., Pérez, W., 2016, A 400-ka tephrochronological framework for Central America from Lake Petén Itzá (Guatemala) sediments: Quaternary Science Reviews, 150, 200-220.

Last, W.M., SmolJ.P., 2001, Anintroduction to basin analysis, coring and chronological techniques used in paleolimnology, in Last, W.M., Smol J.P. (eds.), Tracking Environmental Change Using Lake Sediments. Volume 1: Basin Analysis, Coring, and Chronological Techniques: Dordrecht, Kluwer Academic Publishers, 1-5.

Liberty, L., 2011, Hammer seismic reflection imaging in an urban environment: The Leading Edge, 30(2), 146-153.

Loke, M.H., Barker, R.D., 1995, Least-squares deconvolution of apparent resistivity pseudosections: Geophysics 60(6), 1682-1690.

Lozano-García, S., Ortega, B., Roy, P.D., Beramendi-Orosco, L., Caballero, M., 2015, Climatic variability in the northern sector of the American tropics since the latest MIS 3: Quaternary Research, 84(2), 262-271.

Lozano-García, S., Brown, E.T., Ortega, B., Caballero, M., Werne, J., Fawcett, P.J., Schwalb, A., Valero-Garcés, B., Schnurrenberger, D., O'Grady, R., Stockhecke, M., Steinman, B., CabralCano, E., Caballero, C., Sosa-Nájera, S., Soler, A.M., Pérez, L., Noren, A., Myrbo, A., Bücker, M., Wattrus, N., Arciniega, A., Wonik, T., Watt, S., Kumar, D., Acosta, C., Martínez, I., Cossio, R., Ferland, T., VergaraHuerta, F., 2017, Perforación profunda en el lago de Chalco: reporte técnico: Boletín de la Sociedad Geológica Mexicana, 69(2), 299-311.
Martin del Pozzo, A., 1982, Monogenetic vulcanism in sierra Chichinautzin, Mexico: Bulletin Volcanologique, 45(1), 9-24.

Mollidor, L., Tezkan, B., Bergers, R., Löhken, J., 2013, Float-transient electromagnetic method: in-loop transient electromagnetic measurements on Lake Holzmaar, Germany: Geophysical Prospecting, 61(5), 1056-1064.

Ortega-Guerrero, B., Newton, A.J., 1998, Geochemical characterization of Late Pleistocene and Holocene tephra layers from the Basin of Mexico, Central Mexico: Quaternary Research, 50, 90-106.

Ortega-Guerrero, B., Lozano-García, M., Caballero, M., Herrera-Hernández, D.A., 2015, Historia de la evolución deposicional del lago de Chalco, México, desde el MIS 3: Boletín de la Sociedad Geológica Mexicana, 67(2), 185-201.

Pellerin, L., Hohmann, G.W., 1990, Transient electromagnetic inversion: A remedy for magnetotelluric static shifts: Geophysics, 55(9), 1242-1250.

Pérez-Cruz, G.A., 1988, Estudio sismológico de reflexión del subsuelo de la Giudad de México: Mexico City, Mexico, Universidad Nacional Autónoma de México, Facultad de Ingeniería, MSc Thesis, 83 p.

Ruvalcaba, A., 2009, Modelación matemática del comportamiento hidrogeológico de la zona lacustre de Xochimilco, México: Mexico City, Mexico, Universidad Nacional Autónoma de México, Instituto de Geofísica, MSc Thesis, $107 \mathrm{p}$.

Schindler, D.W., 2009, Lakes as sentinels and integrators for the effects of climate change on watersheds, airsheds, and landscapes: Limnology and Oceanography, 54(6), 2349.

Scholz, C.A., 2001, Applications of seismic sequence stratigraphy in lacustrine basins, in Last, W.M., Smol J.P. (eds.), Tracking Environmental Change Using Lake Sediments. Volume 1: Basin Analysis, Coring, and Chronological Techniques: Dordrecht, Kluwer Academic Publishers, 7-22. 
Szarka, L., 1988, Geophysical aspects of manmade electromagnetic noise in the earth - A review: Surveys in Geophysics, 9(3-4), 287-318.

Telford, W.M., Geldart, L.P., Sheriff, R.E., 1990, Applied geophysics (Vol. 1): Cambridge, Cambridge University Press, 792 p.

Vergara-Huerta, F., 2015, Modelo de velocidad sísmica en la subcuenca de Chalco, Edo. de México, mediante análisis de cocientes $\mathrm{H} / \mathrm{V}$ de vibraciones ambientales: Mexico City, Mexico, Universidad Nacional Autónoma de México, Instituto de Geofísica, MSc Thesis, $101 \mathrm{p}$.
Waxman, M.H., Smits, L.J.M., 1968, Electrical conductivities in oil-bearing shaly sands: Society of Petroleum Engineers Journal, 8(02), 107-122. 